International Journal of Linguistics, Literature and Translation

ISSN: 2617-0299 (Online); ISSN: 2708-0099 (Print)

DOI: $10.32996 / \mathrm{ijlt}$

Journal Homepage: www.al-kindipublisher.com/index.php/ijllt

\title{
The Dominant Language Used on Landscapes in Medan-Indonesia
}

\author{
Maria Olivia Christina Sianipar 8 (D) \\ Lecturer, English Education Department, Faculty of Teacher Training and Education Science, Universitas HKBP Nommensen, \\ Medan, Indonesia \\ $\triangle$ Corresponding Author: Maria Olivia Christina Sianipar, E-mail: mariasianipar919@yahoo.co
}

\author{
ARTICLE INFORMATION \\ Received: May 17, 2021 \\ Accepted: June 21, 2021 \\ Volume: 4 \\ Issue: 6 \\ DOI: $10.32996 /$ ijllt.2021.4.6.17
}

\section{KEYWORDS}

Linguistic Landscape, Dominant Language, Indonesian Language, and English

\section{ABSTRACT}

This study aimed to investigate the dominant language used (English or Indonesian Language) in the linguistics landscape in Indonesia. Therefore, the research method applied in this study was descriptive analysis, and the technique of collecting the data was documentation technique. The finding shows that the dominant language used at malls or shopping centres was English, while at the office building of private companies and streets, the linguistics landscapes were dominantly written in the Indonesian language. However, this research was only focused on the Indonesian and English language used in the linguistics landscape. Therefore, research is suggested to be conducted in more languages and more places for better findings and impact.

\section{Introduction}

\subsection{Background of Study}

Humans need language as means of communication. Language plays an essential role as a means of communication in human life because, with language, humans can interact with each other and talk about anything. Humans as social creatures, of course, and always communicate with other humans. The primary function of language is to interact with humans, a tool for thinking and channelling the meaning of belief in society. Apart from being a means of communication and interaction, language also has an essential meaning as a learning method in the scope of language itself.

Indonesia has a national language, namely Bahasa Indonesia (Indonesian language), which is the language that unites the nation with its diverse culture. Bahasa Indonesia (Indonesian language) was born on October 28, 1928. In the same year, the Indonesian language was designated as the national language. Then on August 18, 1945, the Indonesian language was designated as the state language. As the national language, the Indonesian language has several functions: 1) unifying Indonesian society. The Indonesian language is used as a language to communicate between Indonesians who come from various tribes and cultures, 2) as a national identity, the Indonesian language is the everyday language used and is a characteristic of the Indonesian state, and 3) the Indonesian language pride of the Indonesian nation.

It means that the Indonesian language was made by Indonesians and as a unifying language to communicate with the Indonesian people. Therefore, this function is not much different from the function of unifying or unifying language.

On the other hand, English is used by various nations to communicate with nations around the world. So, English is one of the international languages at the same time a global language, as Crystal (2003) said that English is a global language. Therefore, learning and understanding English is a necessity, which cannot be avoided. By studying English, someone will open his or her horizons and knowledge internationally. That is the reason many Indonesian people have already used English for communication. They use English in both spoken and written languages for international communication.

\section{K C AL-KINDI CENTER \\ $\mathbf{R}$ D FOR RESEARCH AND DEVELOPMENT}

Your gateway to world-class research

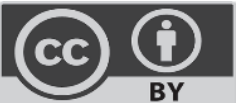

Published by Al-Kindi Center for Research and Development, London, United Kingdom. Copyright (c) the author(s). This open access article is distributed under a Creative Commons Attribution (CC-BY) 4.0 license 


\subsection{Research Objective}

One of the reasons that many linguistics landscapes are written in English is because many Indonesian nowadays are using English for daily and international communication. Therefore, English is like a modern and high-catching language. Therefore, the main objective of this study was to investigate the dominant language used (Indonesian or English languages) on the landscape in Indonesia.

\subsection{Research Question}

Following the Research objectives of this study, the research question is formulated as follows:

1) What is the dominant language used in landscapes in Indonesia?

\section{Review of Literature}

The linguistic landscapes are put in many places, such as roads, offices, hospitals, schools, malls, shops, restaurants, and other public places. The linguistic landscape is on road signs, billboards, graffiti, posters, banners, etcetera. Linguistic landscapes provide essential insights and a different perspective on our knowledge about language.

According to Landry and Bourhis (1997), Linguistics Landscape is the language of public road signs, advertising billboards, street names, place names, commercial shop signs, and public signs on government buildings. Moreover, Spolsky and Cooper (1991) gave three sign rules. They are 1) write signs in a language you know, 2) prefer to write signs in the language or languages that intended readers are assumed to read, and 3) prefer to write signs in your language or in a language with which you wish to be identified. These rules focus on the motivation for using some languages and not others on language signs.

The most prominent areas discussed on the linguistic landscape are multilingualism, the spread of English, differences between top-down and bottom-up signs, and the effect of language policy.

\subsection{Multilingualism}

There are many factors of multilingualism. Globalizations, immigration, the revitalization of minority languages, and tourism have contributed to multilingualism and multiculturalism at the beginning of the $21^{\text {st }}$ century. Ethnic, sociocultural, religious, and commercial diversity contribute to cultural diversity and also to linguistic diversity. Studies on the linguistic landscape conducted in different settings reflect cultural and linguistic diversity in different languages when studying language signs.

\subsection{The Spread of English.}

The linguistic landscape usually includes English as one of the languages used in different contexts in different parts of the world. English can activate international orientation, future orientation, success, sophistication, or fun orientation (Piller, 2001, 2003). Nevertheless, the use of English can also raise issues of identity and power and can have consequences regarding the balance between the languages in bilingual and multilingual situations (Pennycook, 1994: Ammon et al., 1994; Fishman et al., 1996; Philipson, 2003). The process of globalization is made visible through the presence of English in the linguistic landscape in all studies.

\subsection{The Differences Between Top-Down and Bottom-Up Signs}

Studies on the linguistic landscape have found significant differences between these types of signs. They are 1) Top-down signs are 'government' signs such as official signs for street names. These signs reflect a specific language policy: road signs, building names, and street names. 2) Bottom-up signs are personal signs such as the signs on shops, and they may be influenced by language policy but mainly reflect individual preferences: shops, advertising, private offices.

\subsection{The Effect of Language Policy}

Some states and regions include signage as part of their language policy. There is usually a well-developed language policy for the use of languages in the media or education in these areas as Landry and Bourhis (1997) pointed out that using different languages in language signs in bilingual and multilingual countries or regions can be of great symbolic importance. The theoretical development of studies in the linguistic landscape will also develop further and in different directions. The directions are: 1) Education, more research on the linguistic landscape in education is certainly necessary because the linguistic landscape is present both at school and in its environment. Another approach to studying the linguistic landscape in education focuses on language ads in the educational setting and has been carried out in India (Ladousa, 2002). This study shows differences in language use when the advertisements are compared to those of private tutors. There is a trend to use more English in advertisements of private schools than in public schools and private tutoring. 2) Historical dimension, the linguistic landscape is dynamic and changes over time and can be very informative about the role of different languages in different periods. This approach was already discussed in Spolsky and Cooper (1991), who gave fascinating examples about signs in form different periods in Israel. Backhaus (2005) also focused on the diachronic development of the linguistic landscape in Tokyo. The linguistic 
landscape study contributes to the study of cultural heritage because languages are part of the cultural heritage, and the sustainable development of linguistic diversity is seen as an essential aspect of our heritage. 3) Language contact, the study of language contact from a linguistic perspective in language signs, is another area that needs to be developed shortly as Huebner (2006) pointed out that the use of different kinds of contact phenomena on language signs poses several questions regarding the boundaries of speech communities or even the boundaries between languages.

The significant contributions to studying the linguistic landscape and the work in progress and the future directions show that the study of language signs can significantly increase our knowledge about language in different ways.

\subsection{Advertisement}

Advertising is news or messages to encourage the general public to be interested in the goods and services offered, notification to the public regarding goods or services being sold, posted in the mass media (such as newspapers and magazines) or public places. Kriyantono (2008) suggested that advertising is a form of non-personal communication that sells messages persuasively from clear sponsors to influence people to buy products by paying fees for the media used. Wright (1978) argued that advertising is a communication process that has fundamental strengths as a marketing tool that is very helpful in selling goods, providing services and ideas through specific channels in the form of persuasive information. Gilson and Berkman (1980), advertising is a persuasive communication medium designed in such a way as to generate response and helps achieve marketing objectives or marketing purposes. According to them, advertising is a persuasive communication medium designed in such a way as to generate response and helps achieve marketing objectives or marketing purposes.

Based on the definitions above, advertisement is one of the effective communication platforms between messengers and readers. Through advertisement, a messenger will be able to effectively communicate to the readers to get the important message from it. Therefore, investigating the most dominant language used on landscapes in Indonesia is essential to know the most effective language used for written communication in Indonesia.

\section{Research Methodology}

\subsection{Research Design}

This research is conducted by applying qualitative and quantitative methods. Qualitative methods seek to understand and interpret the meaning of an event of human behavior interaction in a particular situation according to the researcher's perspective. Research using qualitative research aims to understand the object under study in depth. The quantitative method is conducted from primer data. The researcher's primary data is data directly collected by the researcher to research the first source (Sugiyono, 2012).

\subsection{Data and Data Collection Technique}

The texts written in pictures (signage and displays) are the data in this study. The data were collected from three main places. They are malls, office buildings (private companies), and streets. The technique used in collecting the data was the documentation technique in which the texts from each advertisement were collected, put, and categorized based on the language used in tables.

\section{Findings and Discussion}

The data were collected through documentation techniques. The data were collected from malls, office buildings, and streets. The findings of this study are presented in the following table.

Table 1. Number of texts on landscapes

\begin{tabular}{|c|c|c|c|c|}
\hline \multirow{2}{*}{ Sources of Data } & \multicolumn{3}{|c|}{ Language } & \multirow{2}{*}{ Tota } \\
\hline & English & Indonesia & Mixed & \\
\hline Malls & 45 & 3 & 7 & 55 \\
\hline Office Buildings & 0 & 10 & 7 & 17 \\
\hline Streets & 10 & 21 & 7 & 38 \\
\hline Total & 55 & 34 & 21 & 110 \\
\hline
\end{tabular}

Table 1 presents the number of text written on a landscape from three different places, malls, office buildings, and streets. Three types of texts were written in the landscape; they were written in Indonesian Language, English, and mixed-languages (Indonesia and English languages). 
Stood at English, complete texts found were 55 texts in which 45 of them were taken from malls, and 10 of them were collected from streets. Zero was from an office building. Furthermore, the total number of text written in the Indonesian language was 34 , of which three were from malls, ten from office buildings, and 21 from streets. Lastly, the total number of texts written in both English and Indonesian languages was 21. Each place presented seven texts. From Table 1, the higher number of text in the landscape was written in English, Then in the Indonesian language, and the last place was in mixed-languages (Indonesian and English languages). The percentages of each language are presented in the following graph.

\section{Percentage (\%)}

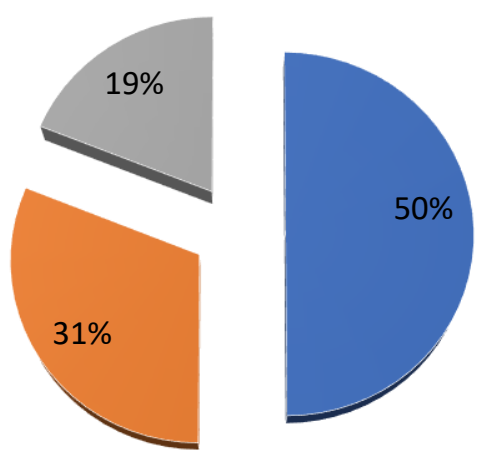

English

- Indonesian Language

Mixed

Figure 1 illustrates the percentage of language used found in the landscape in Indonesia. There were three different languages used in those landscapes. They were English, Indonesian language, and mixed languages (Indonesian and English languages). From 110 texts collected from malls, office buildings, and streets in Indonesia, the English language was the dominant language used in the landscape, 50\%. The second place goes to the Indonesian language, which was $31 \%$, and the last position goes to mixed language, which was $19 \%$ of the total data.

The different place shows different language is the most used. For example, English is the language used primarily in malls. Indonesian language (Bahasa Indonesia) is a minor language in the mall. In contrast, the Indonesian language (Bahasa Indonesia) is the language used most in office buildings. Indonesia language (Bahasa Indonesia) is also most used on the streets, although many fully English texts are used in some areas.

Indonesia is a developing country so that the use of English is expected. That is one reason that English is the language used most in the texts of many kinds of landscapes in Indonesia. There are texts used entirely in one language only, such as Indonesian language and English. There are texts written in both languages/mixtures. They are English and Indonesian language, which are used in one text.

The texts are written that way because the texts are expected to invite or attract people or persuade people or make people understand and agree or believe what they say through the texts. So they have to put persuasive language, and to put innovative language (to suit the changes that are happening in order to stay connected with the audience), and to put strong language (refers to language that has enormous power to change the opinions the actions of the audience) and always creating attractiveness appeal into their texts.

\section{Conclusion}

Investigating the dominant language used (Indonesian or English languages) on the landscape in Indonesia, this study indicates that the English language is dominantly used in a landscape at malls, as the mall is the place for the highly educated and high financial status of citizens of Indonesia. However, even though the Indonesian language is still used at malls, the whole Indonesian language is dominantly found in office buildings and streets because the office should follow government instruction even though private company and landscape at streets are mainly by middle and low-income citizens. 
This study is limited to two languages only (English and Indonesian languages); then, it is also limited to text from three different places (malls, office buildings, and streets). Therefore, further research is suggested in various places and other languages so that the findings and the impact of the research are more relevant and acceptable.

\section{References}

[1] Ammon, U., Mattheier, K.J. and Nelde, P.H.: 1994, English only? In Europe. Sociolinguistics 8 (special issue)

[2] Backhaus, P.: 2005, Signs of multilingualism in Tokyo - a diachronic look at the linguistic landscape. International Journal of the Sociology of Language, 175/176, 103-121.

[3] Crystal, D. (2003). English as a Global Language (Second Edition). Cambridge University Press.

[4] Fishman, J.A., Conrad, A.W. and Rubal-Lopez, A. (eds) (1996) Post-imperial English. The Hague: Mouton de Gruyter.

[5] Huebner, T. (2006) Bangkok's Linguistic Landscapes: Environmental Print, Code Mixing, and Language Change. The International Journal of Multilingualism 3, 31-51.

[6] Gilson, C. C. \& Berkman, H. W. (1980). Advertising Concepts and Strategies. Michigan: Random House

[7] Kriyantono (2008). Teknik Praktis Kiat Komunikasi. Jakarta: Kencana Prenada Media Group

[8] Ladousa, C. (2002) Advertising in the periphery: languages and schools in a North Indian city. Language in Society 31, $213-242$.

[9] Landry, R. and Bourhis, R.Y. (1997) Linguistic landscape and ethnolinguistic vitality: An empirical study, Journal of Language and Social Psychology 16 (1), 23-49. https://doi.org/10.1177/0261927X970161002

[10] Pennycook, A. (1994). The Cultural Politics of English as an International Language. London: Longman.

[11] Phillipson, R. (2003) English-only Europe? Challenging language policy. London: Routledge

[12] Piller, I. (2001) Identity constructions in multilingual advertising. Language in Society 30 (1), 153-186.

[13] Piller, I. (2003) Advertising as a site of language contact. Annual Review of Applied Linguistics 23 (1), 170-183.

[14] Spolsky, B. and Cooper, R.L. (1991) The Languages of Jerusalem. Oxford: Clarendon Press.

[15] Sugiyono. 2012. Metode Penelitian Kuantitatif Kualitatif dan R\&B. Bandung: Alfabeta.

[16] Wright, P. L. (197\&). Analyzing media effects on advertising responses. Public Opinion Quarterly, 38, 192-205.

\section{Appendix}

Texts in landscape in Indonesia

\begin{tabular}{|c|c|c|}
\hline Indonesian Language & English & Mixed-Languages \\
\hline Kopi Kenangan & 4 Fingers Crispy Chicken & Basement Keluar \\
\hline $\begin{array}{l}\text { Dilarang Berada Dan Menggunakan } \\
\text { Tangga Darurat }\end{array}$ & Archa Photo & $\begin{array}{l}\text { Chop Buntut Paket Nasi Kotak Extra } \\
\text { Order Drink }\end{array}$ \\
\hline Maaf Ada Pemeriksaan & Auntie Anne's & Evacuation Route Jalur Evakuasi \\
\hline Perhatian Tentang Kendaraan & Books \& Beyond & $\begin{array}{lll}\text { Pos Pembayaran Parkir Parking } \\
\text { Payment Station }\end{array}$ \\
\hline $\begin{array}{l}\text { Mohon Jangan Buang Sampah Di } \\
\text { Tempat Ini }\end{array}$ & Bread Life & Ayo Titipin Helm Di Basement \\
\hline $\begin{array}{l}\text { Terimakasih Telah Membuang Sampah } \\
\text { Pada Tempatnya }\end{array}$ & Bread Talk & $\begin{array}{l}\text { Open / Buka Italian Fusion Pizza Pasta } \\
\text { Coffee Dessert }\end{array}$ \\
\hline $\begin{array}{lrrr}\text { Terimakasih Telah } & \text { Parkir } & \text { Tidak } \\
\text { Melewati Garis Parkir } & & \end{array}$ & Buana Photo & Motor Parking - To Masjid Agung \\
\hline $\begin{array}{l}\text { Terimakasih Telah Parkir Tidak } \\
\text { Melewati Garis Parkir }\end{array}$ & Cashier & $\begin{array}{l}\text { Maksimal Kecepatan Kendaraan } 5 \mathrm{~km}- \\
\text { Maximum Speed Of The Vehicle } 5 \mathrm{~km}\end{array}$ \\
\hline Parkir Tamu Roda Dua & Century & $\begin{array}{l}\text { Hati Hati Jalur Penyeberangan Pejalan } \\
\text { Kaki-Carefully Pedestrian Crosswalks }\end{array}$ \\
\hline Dilarang Merokok & Chatime & Akses Pejalan Kaki Pedistrian Access \\
\hline Masuk & Chopping Station & $\begin{array}{l}\text { Ada Pemeriksaan Sekuriti Dan } \\
\text { Pemberian Kartu Parkir-Security } \\
\text { Check And Giving Of Parking Park }\end{array}$ \\
\hline Mintalah Kartu Parkir Kepada Petugas & Fountain & Titik Kumpul Muster Point \\
\hline
\end{tabular}




\begin{tabular}{|c|c|c|}
\hline Parkir Karyawan - Parkir Tamu & $\begin{array}{l}\text { Fuwa Japanese Authentic Fluffy } \\
\text { Cake }\end{array}$ & Area Merokok Smoking Area \\
\hline Bakso Mas Mardi & Frank \& Co. & $\begin{array}{l}\text { Safety First Utamakan Keselamatan } \\
\text { Dan Kesehatan Kerja }\end{array}$ \\
\hline Bengkel Las Marisi Kasih & In Time & Text In Bahasa Indonesia And English \\
\hline Warkop Surbakti & Kesawan Jewellery & $\begin{array}{l}\text { Terimakasih Anda Telah Menjadi } \\
\text { Bagian Dari } 1001 \text { Mitra Laundry King } \\
\text { Wash }\end{array}$ \\
\hline Warung Kopi Bersama & Kinley Bangkok Street Food & Opple Lighting Budi Jaya \\
\hline Kedai Serba Sambal Sensasi Pedas & Let'us Go Gelato & Ali Tattoo Sulam Beauty Care \\
\hline Ki Af Pangkas & Liang Sandwich Bar & Jaya Audio - Auto Accessories Centre \\
\hline Mari Pangkas & $\begin{array}{l}\text { Lift Mall- North Lobby- Main } \\
\text { Lobby }\end{array}$ & $\begin{array}{l}\text { Ss Fried Chicken Dapat Dipesan Di Go } \\
\text { Food }\end{array}$ \\
\hline Apotik Inti & $\begin{array}{l}\text { Lift Mall-Cosmetics-Food } \\
\text { Baverages-Optic }\end{array}$ & $\begin{array}{l}\text { Kantor Perwakilan Pantai Hospital } \\
\text { Penang }\end{array}$ \\
\hline Martabak Gama & Maxx Coffee & Graha Bakery And Cake Shop \\
\hline Tarif Parkir & Miss Mondial & \\
\hline Kantor Lurah & Mr Speed & \\
\hline Nasi Telor Sentosa & No Smoking & \\
\hline Pecal Embak Nur & Offle Don't Try It & \\
\hline Jalur Pengantar Penjemput Sekolah & Ok Shop & \\
\hline Patuhilah Rambu Lalu Lintas & Pappa Rich & \\
\hline Jalur Arah Kantor Walikota & Pepper Lunch & \\
\hline $\begin{array}{l}\text { Dilarang Menaikkan / Menurunkan } \\
\text { Penumpang } \\
50 \text { Meter Kedepan }\end{array}$ & Point Break & \\
\hline Belawan - Tg Morawa Jalan Tol & $\begin{array}{lll}\text { Rest } & \text { Room- } & \text { Escalator-Lift } \\
\text { Parking } & & \\
\end{array}$ & \\
\hline $\begin{array}{l}\text { Khusus Jalur Masuk \& Keluar Mobil \& } \\
\text { Pejalan Kaki }\end{array}$ & $\begin{array}{l}\text { Liang Sandwich Bar } \\
\text { Order Here }\end{array}$ & \\
\hline $\begin{array}{lcc}\text { Hati-Hati } \quad \text { Bahaya } & \text { Tersandung } \\
\text { Perhatikan Langkah Anda } & \\
\end{array}$ & Swatch & \\
\hline \multirow[t]{18}{*}{ Satu Arah } & Tea Amo & \\
\hline & The Athletes Foot & \\
\hline & The Face Shop & \\
\hline & The Mandheling Coffee & \\
\hline & This Is April & \\
\hline & Tv Shopping & \\
\hline & Ultima Delicate Lipstick & \\
\hline & Uncle K & \\
\hline & Watch Engine & \\
\hline & Women's Restroom & \\
\hline & Hokaido Ice Cream Puff & \\
\hline & Sam's & \\
\hline & Barber Shop & \\
\hline & Cheese Bomb & \\
\hline & Cindy Décor & \\
\hline & Foto Copy & \\
\hline & K Link & \\
\hline & King's Barber Shop & \\
\hline
\end{tabular}




\begin{tabular}{|l|l|l|}
\hline & Sir Salon & \\
\hline & Sp Net Internet \& Game Online & \\
\hline & Star Medan Auto Service & \\
\hline & V.O. Coffee & \\
\hline
\end{tabular}

